\title{
Evaluasi Potensi Antidiabetes Sari Buah Markisa Ungu (Passiflora edulis var edulis) pada Tikus Model Diabetes Melitus yang Diinduksi Aloksan
}

\section{Antidiabetic Evaluation of Purple Passion Fruit (Passiflora edulis var edulis) Juice in Diabetic Rats Model Induced by Alloxan}

\author{
Alfi Muntafiah ${ }^{1}$, Tisna Sendy $P^{1}$, Viva Ratih $B A^{2}$ \\ ${ }^{1}$ Laboratorium Biokimia Fakultas Kedokteran Universitas Jenderal Soedirman Purwokerto \\ ${ }^{2}$ Laboratorium Farmakologi Fakultas Kedokteran Universitas Jenderal Soedirman Purwokerto
}

\begin{abstract}
ABSTRAK
Markisa ungu mengandung komponen nutrisi dan fitokimia non nutrisi, dan potensinya pada beberapa kondisi medis telah dilaporkan. Penelitian ini bertujuan mengeksplorasi potensi antidiabetes sari markisa ungu. Penelitian true experimental ini menggunakan 30 ekor tikus putih (Rattus norvegicus) jantan galur Wistar, dibagi 5 kelompok: I) kontrol normal, II) kontrol DM, dan III, IV, V perlakuan sari markisa ungu dosis 1,05; 2,1; dan 4,2mL/200gBB/hari melalui sonde, selama 21 hari. Induksi diabetes dengan aloksan intraperitoneal 120mg/kgBB dosis tunggal. Sampel darah diambil sebelum induksi, setelah induksi dan setelah perlakuan, melalui vena infra orbita. Kadar GDP diukur menggunakan spektrofotometer. Uji Wilcoxon terhadap kadar GDP pasca induksi dan perlakuan, didapatkan p=0,000, menunjukkan perbedaan signifikan kadar GDP antar kelompok normal dan DM. Uji Kruskal-Wallis terhadap kadar GDP pasca perlakuan juga demikian, didapatkan $p<0,05$. Uji post hoc Mann-Whitney: I vs II $p=0,006$; I vs III $p=0,006$; I vs IV $p=0,045$; I vs V $p=0,025$; II vs III $p=0,361$; II vs IV $p=0,917$; II vs V $p=0,584$; III vs IV $p=0,715$; III vs V $p=1,000$; IV vs V $p=0,584$, yang berarti perbedaan hanya antara kelompok normal dengan kelompok diabet dengan atau tanpa perlakuan sari markisa ungu, namun tidak ada perbedaan antar kelompok DM tanpa atau dengan perlakuan sari markisa ungu. Kesimpulan penelitian adalah tidak terdapat perbedaan kadar GDP antara kelompok kontrol DM dengan kelompok yang diberi perlakuan sari markisa ungu berbagai dosis.
\end{abstract}

Kata Kunci: Aloksan, diabetes melitus, markisa ungu, Passiflora edulis var edulis

\begin{abstract}
Purple passion fruit contains nutritional components and non-nutritional phytochemicals, and their potential for several medical conditions has been reported. This study aimed to explore the antidiabetic potential of purple passion fruit juice. This true experimental study used 30 Wistar strain male rats (Rattus norvegicus) which were divided into 5 groups: I (normal control), II (DM control), and III, IV, V purple passion fruit juice treatment dose of $1.05 \mathrm{ml}, 2.1 \mathrm{ml}$, and $4.2 \mathrm{ml} / 200 \mathrm{gBW} /$ day, respectively, through sonde for 21 days. Diabetes induction was made intraperitoneal by a single dose of alloxan 120mg/kgBW. Fasting blood glucose (FBG) samples were taken through the infra-orbital vein before induction, after induction, and after treatment. The FBG level was measured using a spectrophotometer. The Wilcoxon test on FBG levels post-induction post-treatment, $p=0.000$, showed a significant difference among groups. The Kruskal-Wallis test for post-treatment GDP levels was $p<0.05$. Mann-Whitney post hoc test, I vs II $p=0.006$; I vs III $p=0.006$; I vs IV $p=0.045$; I vs V $p=0.025$; II vs III $p=0.361$; II vs IV $p=0.917$; II vs V $p=0.584$; III vs IV $p=0.715$; III vs V $p=1,000 ;$ IV vs V $p=0.584$, indicated that the difference was only between normal and diabetic groups, but no significant difference among DM groups with or without purple-passion fruit juice. This study concluded that there was no difference in FBG levels among the groups of DM control and those treated with various doses of purple passion fruit juice.
\end{abstract}

Keywords: Alloxan, diabetes mellitus, Passiflora edulis var edulis, purple passion fruit

Korespondensi: Korespondensi: Alfi Muntafiah. Laboratorium Biokimia Fakultas Kedokteran Universitas Jenderal Soedirman Purwokerto, Jl. Dr. Gumbreng Purwokerto Jawa Tengah 53112 Telp 085865137470 Email: alfimuntafiah99@gmail.com

DOI: http://dx.doi.org/10.21776/ub.jkb.2019.030.03.5 


\section{PENDAHULUAN}

Diabetes melitus (DM) merupakan penyakit metabolik dengan etiologi multifaktor, yang seringkali merupakan kombinasi faktor genetik, pola hidup kurang aktifitas jasmani dan lingkungan. Diabetes melitus ditandai dengan tingginya kadar glukosa dalam darah yang diakibatkan oleh defek sekresi insulin, kerja insulin, atau keduanya (1-3). Di seluruh dunia, prevalensi penyakit ini terus meningkat dengan cepat, dan pada tahun 2003 jumlah penderita DM telah mencapai proporsi epidemi (4). International Diabetes Federation (IDF) menyatakan bahwa sekitar 371 juta penduduk dunia menderita diabetes. Indonesia termasuk dalam 10 negara dengan jumlah pasien diabetes terbanyak, menempati urutan ke tujuh. Pada tahun 2030 diperkirakan 552 juta penduduk di dunia menderita diabetes, dan $85 \%$ penderita diabetes tersebut berada di negara berkembang (5).

Pengobatan dengan menggunakan produk dari tanaman sudah lama diketahui sejak zaman kuno. World Health Organisation (WHO) memperkirakan sekitar $80 \%$ total populasi pada negara berkembang masih percaya pada tanaman obat, untuk mencegah maupun sebagai pengobatan pertama yang mereka perlukan (6). WHO juga menyetujui penggunaan tanaman herbal untuk berbagai penyakit, termasuk diantaranya DM. Berbagai tanaman obat dan produknya, telah dilaporkan dalam berbagai literatur dapat digunakan untuk mengendalikan diabetes. Penelitian dan studi epidemiologi juga menunjukkan pentingnya mengkonsumsi buah-buahan dan sayuran setiap hari untuk membantu menjaga kesehatan tubuh, menurunkan risiko penyakit kardiovaskuler, kanker dan berbagai penyakit kronik, karena berbagai komponen yang dikandungnya (7).

Spesies Passiflora ditemukan tumbuh di hampir semua negara di dunia. Salah satu jenis spesies yang telah berhasil dibudidayakan di Indonesia yaitu Passiflora edulis var. edulis Sims. Tanaman buah tropis asli Brazil ini, sering kita temukan tumbuh di lingkungan sekitar kita. Berbagai penelitian mengenai markisa ungu, menyebutkan bahwa buah ini banyak mengandung komponen nutrisi $(8,9)$. Selain itu, buah eksotis penuh citarasa ini memiliki nilai kesehatan karena mengandung komponen fitokimia non nutrisi $(6,10)$.

Berbagai penelitian untuk eksplorasi potensi markisa ungu untuk pengobatan herbal pada berbagai kondisi medis banyak dilakukan, mulai dari bagian akar, batang, daun, kulit buah, sari buah, hingga bijinya. Melalui penelitian sebelumnya, peneliti telah mengeksplorasi potensi anti hiperkolesterolemia (11). Kelanjutan dari penelitian tersebut, masih fokus pada sari buah markisa ungu, peneliti ingin mengeksplorasi potensi sari buah markisa ungu sebagai agen anti diabetes pada tikus model DM yang diinduksi aloksan.

\section{METODE}

\section{Hewan Coba}

Penelitian ini merupakan eksperimental murni mengunakan pre pasca test with control group design. Penelitian digunakan 30 tikus putih jantan (Rattus norvegicus), galur Wistar, berusia 2-3 bulan, dengan berat 150-260gram. Hewan coba diperoleh dari LPPT III Universitas Gadjah Mada Yogyakarta. Ethical Approval penelitian diperoleh dari Komisi Etik Fakultas Kedokteran
Universitas Jenderal Soedirman (UNSOED) Nomor Ref: 2185/KEPK/V/2018. Hewan coba diaklimatisasi selama 7 hari, dipelihara dalam suhu sekitar $24^{\circ} \mathrm{C}$ dan kelembaban $55 \%$ serta memperoleh pencahayaan (siklus gelap terang selama 12 jam) yang cukup. Selanjutnya, hewan coba dibagi secara acak dalam 5 kelompok (masing-masing kelompok terdiri dari 6 ekor tikus), yaitu I) kontrol normal, II) kontrol DM, III) perlakuan pemberian sari buah markisa ungu dosis 1,05ml/200 gBB/hari, IV) perlakuan pemberian sari buah markisa ungu dosis $2,1 \mathrm{ml} / 200 \mathrm{gBB} /$ hari, dan V) perlakuan pemberian sari buah markisa ungu dosis $4,2 \mathrm{ml} / 200 \mathrm{gBB} /$ hari. Hewan coba ditempatkan dalam kandang individu dengan bentuk, ukuran, dan bahan yang sama. Selama masa aklimatisasi hingga masa perlakuan selesai, hewan coba mendapatkan pakan AD II dan minuman akuades ad libitum.

\section{Induksi Diabetes}

Induksi DM dilakukan pada kelompok kontrol DM (kelompok II), dan kelompok perlakuan (kelompok III, IV, dan V) dengan menggunakan aloksan monohidrat $120 \mathrm{mg} / \mathrm{kg}$ BB yang dilarutkan ke dalam $0,9 \% \mathrm{NaCl}$, dosis tunggal secara intraperitoneal (i.p) (12-15). Konfirmasi hiperglikemia dilakukan pada hari ke-5 pasca induksi, setelah sebelumnya tikus dipuasakan terlebih dahulu selama 12 jam. Tikus dengan kadar GDP $\geq 200 \mathrm{mg} / \mathrm{dL}$ dianggap hiperglikemia dan digunakan sebagai subjek pada penelitian ini $(16,17)$.

\section{Pembuatan Sari Markisa Ungu}

Buah markisa ungu masak diperoleh dari kawasan perkebunan Wonosobo, Jawa Tengah. Determinasi tanaman markisa ungu secara makroskopis dilakukan di Laboratorium Lingkungan Fakultas Biologi UNSOED, dengan nomor sertifikat 2116/UN23.02.8/PP.08.00/2018. Pembuatan sari buah markisa ungu diawali dengan pencucian buah segar dengan air, selanjutnya buah markisa ungu dibelah menjadi dua bagian. Daging buah markisa ungu diambil, kemudian disaring menggunakan kain saring untuk memisahkan bagian bijinya sehingga didapatkan sari markisa. Sari buah markisa ungu dibuat setiap hari selama masa perlakuan, untuk mendapatkan sari buah yang segar.

\section{Pengambilan Sampel Darah}

Sampel darah diambil sebanyak 3 kali, yaitu pada masa aklimatisasi/pra induksi (awal), setelah induksi (pre test), dan setelah masa perlakuan (pemberian sari markisa ungu) selesai (pasca test). Sebelum dilakukan pengambilan sampel darah, tikus dipuasakan semalam (12 jam). Pengambilan darah dilakukan melalui vena infraorbita sebanyak $3 \mathrm{ml}$. Sampel darah dimasukkan ke dalam tabung non-EDTA, disimpan pada suhu ruangan selama 45 menit, disentrifugasi dengan kecepatan $1300 \mathrm{~g}$ selama 10 menit. Serum yang terbentuk dilakukan analisis kadar glukosa darah puasa (GDP) (18).

\section{Pemeriksaan Kadar Glukosa Darah Puasa (GDP)}

Analisis kadar glukosa darah dilakukan dengan menggunakan glucose kits (DiaSys Diagnostic Systems GmbH Alte Strasse 965558 Holzheim Germany) melalui metode enzimatik-fotometrik. Sebanyak $10 \mu$ l sampel ditambah dengan $1 \mathrm{ml}$ reagen, kemudian divortex dan diinkubasi selama 20 menit pada suhu ruang. Campuran kemudian dibaca absorbansinya dengan menggunakan spektrofotometer RT-1904C Semi-Auto Chemistry 
Analyzer pada panjang gelombang 546nm.

\section{Analisis Statistik}

Data dinyatakan dalam bentuk grafik histogram. Analisis statistik dilakukan dengan menggunakan IBM SPSS versi 15. Sebaran data dinilai normalitasnya dengan ShapiroWilk, sedangkan homogenitas data dengan Levene test. Uji T-test dilakukan terhadap kadar GDP awal vs pascainduksi untuk mengetahui keberhasilan induksi, serta terhadap kadar GDP pasca induksi vs pasca perlakuan untuk mengetahui keberhasilan perlakuan dengan sari markisa ungu. Uji non parametrik Kruskal Wallis (karena tidak memenuhi syarat uji one way ANOVA) dilakukan untuk mengetahui adanya perbedaan rerata antar kelompok perlakuan markisa ungu berbagai dosis.

\section{HASIL}

Selama masa penelitian, tidak tampak adanya perubahan perilaku yang mencolok pada hewan coba seperti disstress, hair loss, konfulsi, maupun lainnya. Kelompok kontrol normal cukup aktif, sementara pada kelompok DM, hewan coba tampak sakit, lebih kurus, bulu pucat dan tampak kotor. Selanjutnya pada pada akhir masa perlakuan, pada kelompok perlakuan, bulu hewan coba terlihat lebih mengkilat dan lebih aktif dibandingkan dengan kelompok kontrol DM.

Berat badan hewan coba

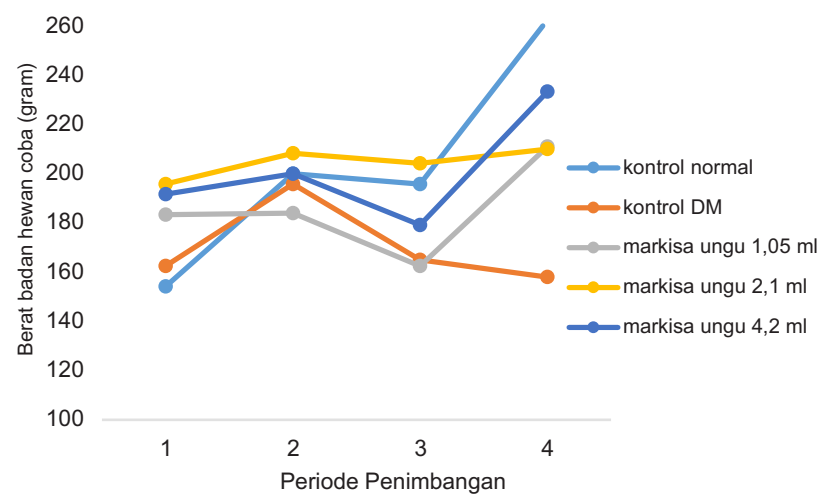

Gambar 1. Grafik berat badan hewan coba selama masa penelitian

Gambar 1. menunjukkan grafik berat badan hewan coba selama masa penelitian. Bobot badan hewan coba diukur sebanyak 4 kali: 1) awal masa aklimatisasi 2) pre induksi, 3) perlakuan minggu pertama, 4) perlakuan minggu ketiga. Bobot badan awal berada dalam rentang $\pm 150-260$ gram. Selama masa aklimatisasi, bobot badan hewan coba pada semua kelompok cenderung naik. Setelah induksi diabetes, bobot badan hewan coba cenderung menurun dan meningkat kembali hingga masa perlakuan berakhir, kecuali pada kelompok kontrol DM bobot badan cenderung terus menurun. Bobot badan pada kelompok yang tidak diinduksi (kontrol normal), cenderung stabil. Pada kelompok kontrol diabetes, berat badan hewan coba cenderung terus menurun, sedangkan kelompok perlakuan sari markisa ungu dan kelompok kontrol normal cenderung meningkat.
Kadar glukosa darah puasa (GDP)

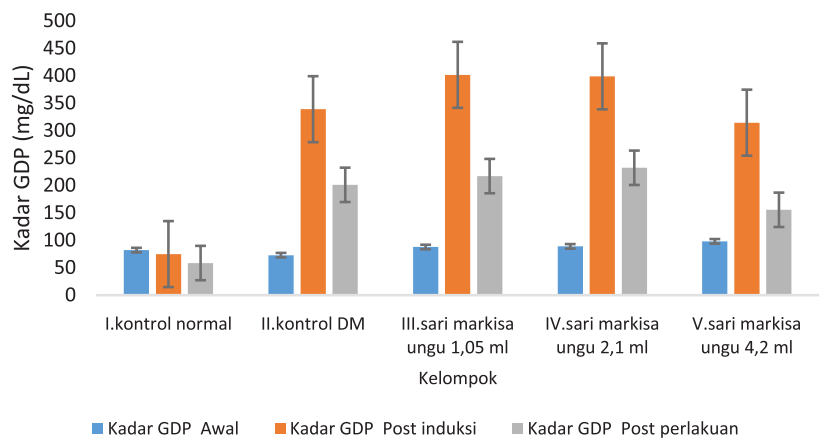

Gambar 2. Kadar glukosa darah puasa (GDP) selama masa penelitian

Keterangan: Grafik batang GDP (rerata dan simpangan baku) sebelum induksi aloksan (biru), periode setelah induksi aloksan pada kelompok II-V (jingga), dan periode setelah pemberian sari markisa ungu (abu-abu) menunjukkan peningkatan GDP yang diikuti dengan penurunan GDP pada kelompok yang diinduksi aloksan baik dengan atau tanpa pemberian sari markisa ungu.

Kadar GDP selama masa penelitian ditunjukkan pada Gambar 2. Berdasarkan Gambar 2, diketahui bahwa kadar GDP awal pada semua kelompok $<100 \mathrm{mg} / \mathrm{dL}$. Pemeriksaan kadar GDP pasca induksi dilakukan pada hari ke-5 pasca induksi aloksan, pada kelompok II, III, IV, dan V didapatkan adanya peningkatan kadar GDP secara signifikan sebesar 3-4 kali lipat dibandingkan kadar GDP awal. Hal ini menunjukkan keberhasilan induksi DM dengan menggunakan aloksan $120 \mathrm{mg} / \mathrm{kgBB}$ dosis tunggal secara intra peritoneal. Pemeriksaan kadar GDP pasca-perlakuan dilakukan pada akhir masa penelitian. Uji Kruskal-Wallis terhadap kadar GDP pasca perlakuan didapatkan nilai $p<0,05$, selanjutnya dilakukan uji post Hoc Mann-Whitney. Hasil uji Mann-Whitney menunjukkan adanya perbedaan yang signifikan antara kadar GDP pasca perlakuan pada kelompok I dengan kelompok II, III, IV, dan V (I vs II $p=0,006$; I vs III $p=0,006$; I vs IV $p=0,045$; I vs V $p=0,025$ ). Sementara itu kadar GDP post perlakuan antara kelompok II dengan kelompok III, IV dan V tidak didapatkan adanya perbedaan yang signifikan (II vs III $p=0,361$; II vs IV $p=0,917$; II vs V $p=0,584$; III vs IV $p=0,715$; III vs V $p=1,000$; IV vs V $p=0,584$ ). Hal ini berarti bahwa secara statistik kadar GDP pada kelompok yang diberi sari markisa ungu dosis $1,05 \mathrm{ml}$, 2,1ml, dan 4,2ml/200 gBB/hari sama dengan kadar GDP kelompok kontrol DM. Penurunan (delta) kadar GDP oleh pemberian perlakuan sari markisa ungu dosis 1,$05 ; 2,1$, dan 4,2ml/200 gBB, secara berturut turut sebesar $184,62 \mathrm{mg} / \mathrm{dL}, 166,72 \mathrm{mg} / \mathrm{dL}$, dan $158,93 \mathrm{mg} / \mathrm{dL}$. Kadar GDP pasca perlakuan masih berada di atas rentang kadar GDP kelompok kontrol normal.

\section{DISKUSI}

Saat ini pengobatan dengan menggunakan tanaman herbal sudah digunakan secara luas. Hal ini bisa dilihat dari berbagai studi yang menunjukkan efek tanaman herbal dan buah buahan terhadap profil biokimiawi, diantaranya pada hewan coba tikus model diabetes yang diinduksi streptozotosin maupun aloksan, seperti ceri (14), madu (19), Ficus glomerata (12), Icacina senegalensis (17), dan lain lain. Aloksan dan streptozotosin merupakan agen diabetogenik populer yang seringkali digunakan pada berbagai penelitian untuk mengetahui kapasitas 
hipoglikemik suatu senyawa. Aloksan relatif lebih murah dan lebih mudah didapatkan (20) sehingga peneliti memilih agen diabetogenik ini untuk menginduksi diabetes. Induksi diabetes pada penelitian ini menggunakan dosis $120 \mathrm{mg} / \mathrm{kg}$ BB dosis tunggal secara intraperitoneal, mengacu pada studi eksperimental yang dilakukan oleh beberapa peneliti sebelumnya, yaitu Sharma et al., Lachin \& Reza, Shah \& Khan, dan Sarasa et al. $(12,14,15,21)$. Selain itu, peneliti memilih rentang dosis ini karena tidak menimbulkan efek mortalitas (22). Penggunaan dosis $120 \mathrm{mg} / \mathrm{KgBB}$ ini lebih rendah daripada dosis yang telah digunakan oleh peneliti pada penelitian sebelumnya, yang menggunakan dosis $160 \mathrm{mg} / \mathrm{kg}$ BB (19), maupun dosis yang digunakan dalam penelitian Sharma et al., yaitu dosis $150 \mathrm{mg} / \mathrm{kg}$ BB (23). Pada penelitian ini, hasil induksi dengan aloksan $120 \mathrm{mg} / \mathrm{kgBB}$ dosis tunggal secara intraperitoneal menunjukkan peningkatan secara signifikan kadar GDP pada hari ke-5 pasca induksi, sebesar 3-4 kali lipat dibandingkan kadar GDP awalnya.

Berdasarkan data pada Gambar 1 diketahui adanya penurunan rerata bobot badan hewan coba pada kelompok yang diinduksi DM. Penurunan bobot badan oleh karena kondisi hiperglikemia pada hewan coba ini juga ditemukan pada penelitian lain, yang menyatakan bahwa terdapat hubungan antara hiperglikemia dengan penurunan bobot badan pada tikus model diabetik $(17,24)$. Penurunan bobot badan dapat disebabkan oleh ketidakmampuan tubuh untuk menggunakan glukosa sebagai sumber energi, oleh karenanya kebutuhan energi kemudian diperoleh dari lemak berbagai jaringan. Selain itu, penurunan bobot badan dapat diakibatkan oleh pengambilan energi dari otot maupun hati melalui proses glukoneogenesis (25). Sementara itu bobot badan pada kelompok perlakuan mengalami trend peningkatan. Hal ini bisa dimungkinkan karena perbaikan sekresi insulin oleh karena efek perlakuan, yang akan mengurangi kondisi hiperglikemia dan akhirnya memperbaiki bobot badannya.

Potensi antidiabetes beberapa spesies Passiflora telah diteliti, diantaranya Passiflora ligularis $(2,3)$ dan Passiflora edulis (26-28). Penelitian oleh Anusoriya et al., mengungkapkan potensi antidiabetes ekstrak buah Passiflora ligularis (2). Sementara itu George et al., juga mengemukakan adanya potensi yang sama pada daun Passiflora ligularis (3). Potensi antidiabetes Passiflora edulis diungkapkan oleh Salgado et al., yang menemukan bahwa tepung kulit buah Passiflora edulis konsentrasi $5 \%$ dapat menurunkan kadar glukosa darah sebesar $59 \%$ dan meningkatkan kadar glikogen hepar sebesar 71\% (26). Sementara itu Barbalho et al., pada penelitiannya menyatakan bahwa sari markisa dapat menurunkan kadar GDP dan dapat digunakan untuk mencegah diabetes dan komplikasinya (27). Penelitian oleh Kanakasabapathi \& Gopalakrishnan juga menemukan potensi antidiabetes ekstrak daun markisa ungu (28).

Pada penelitian ini, pemberian perlakuan sari markisa ungu dosis 1,05; 2,1; dan 4,2ml/200 gBB/hari selama 21 hari secara statistik tidak menurunkan kadar GDP secara signifikan. Penelitian ini tidak sejalan dengan penelitian Barbalho et al., yang menyatakan bahwa pemberian perlakuan dengan sari markisa ungu dosis $200 \mathrm{~g} / \mathrm{L}$ dapat menurunkan kadar GDP secara signifikan (27). Penurunan GDP mungkin berkaitan dengan berbagai fitokimia yang terkandung dalam sari buah markisa ungu (Passiflora edulis var edulis). Pada ekstrak berbasis air (sari buah) markisa ungu, terdapat komponen mineral, karotenoid, vitamin C dan flavonoid. Antioksidan yang terkandung dalam vitamin dan flavonoid disebutkan memiliki efek positif dalam penatalaksanaan dan pencegahan hiperglikemia (27). Flavonoid bekerja melalui kemampuannya menghambat absorpsi glukosa, menstimulasi pengambilan glukosa pada jaringan perifer, mengatur aktivitas dan ekspresi enzim yang terlibat dalam jalur metabolisme karbohidrat dan bertindak menyerupai insulin sehingga berdampak pada penurunan GDP. Flavonoid juga memperbaiki resistensi insulin perifer (29). Kandungan senyawa dalam markisa ungu ini mungkin bisa menjelaskan pengaruh tanaman ini dalam mengontrol hiperglikemia pada model hewan coba diabetes.

Pada penelitian ini penurunan kadar GDP oleh ketiga dosis perlakuan markisa ungu tersebut tidak terlalu berbeda. Pemberian perlakuan sari markisa ungu dosis 1,$05 ; 2,1$; dan $4,2 \mathrm{ml} / 200$ gBB secara berturut turut dapat menurunkan kadar GDP sebesar $184,62 \mathrm{mg} / \mathrm{dL}$, $166,72 \mathrm{mg} / \mathrm{dL}$, dan $158,93 \mathrm{mg} / \mathrm{dL}$. Disisi lain, kelompok kontrol DM (tidak mendapatkan perlakuan sari markisa ungu) juga mengalami penurunan kadar GDP yang signifikan sebesar $137,96 \mathrm{mg} / \mathrm{dL}$. Oleh karena itu, pada penelitian ini, peneliti tidak dapat menyatakan bahwa penurunan kadar GDP tersebut disebabkan oleh efek perlakuan sari markisa ungu. Peneliti menganalisis adanya kemungkinan faktor lain yang menyebabkan penurunan kadar GDP tersebut, diantaranya yaitu efek reversibilitas spontan dari aloksan. Chougale et al., dalam penelitiannya menyebutkan bahwa induksi diabetes secara intraperitoneal dengan aloksan dosis $120 \mathrm{mg} / \mathrm{kgBB}$ dan $140 \mathrm{mg} / \mathrm{kgBB}$ dapat meningkatkan glukosa darah pada kadar $127 \pm 5 \mathrm{mg} / \mathrm{dL}$ dan $232,5 \pm 4,5 \mathrm{mg} / \mathrm{dL}$ selama periode waktu 4-5 hari, namun kadar glukosa darah dapat kembali normal pada hari ke-9 tanpa intervensi medis apapun (30). Pada penelitian kali ini dosis aloksan $120 \mathrm{mg} / \mathrm{kgBB}$ dapat meningkatkan kadar glukosa darah pada level 350$400 \mathrm{mg} / \mathrm{dl}$ pada periode lima hari pasca induksi, namun pada akhir penelitian (hari ke 22) kadar glukosa darah berada pada rentang $150-230 \mathrm{mg} / \mathrm{dl}$. Efek diabetogenik aloksan yang bervariasi ini antara lain dapat dipengaruhi oleh spesies hewan coba $(31,32)$, bahkan pada spesies yang sama pun sangat bervariasi (32). Status nutrisi juga mempengaruhi sensitivitas aloksan (31). Hewan coba yang diberi pakan tinggi lemak lebih rentan terhadap aloksan dibandingkan yang diberi pakan tinggi karbohidrat dan protein (20). Hewan coba yang berpuasa lebih rentan terhadap aloksan. Sementara itu, kadar glukosa darah yang tinggi dapat mengurangi kerusakan sel $\beta$ pankreas yang disebabkan oleh pemberian aloksan. Hal ini disebabkan oleh efek perlindungan glukosa, dimana glukosa bersaing dengan aloksan pada transporter glukosa GLUT 2 (31).

Kesimpulan penelitian ini, tidak terdapat perbedaan antara kadar GDP pada kelompok kontrol DM dengan kelompok yang diberi perlakuan sari markisa ungu berbagai dosis, karena hewan model diabetes diduga mengalami pemulihan kondisi dengan atau tanpa perlakuan sari markisa ungu. Evaluasi manfaat dan dosis sari markisa ungu untuk menurunkan kadar GDP dengan baik perlu dilakukan pada penelitian selanjutnya menggunakan metode lain yang menjamin keberhasilan pembuatan hewan model diabetes.

\section{UCAPAN TERIMAKASIH}

Ucapan terimakasih kami sampaikan kepada Universitas Jenderal Soedirman Purwokerto, atas hibah dana BLU UNSOED melalui Skema Riset Peningkatan Kompetensi yang telah diberikan untuk penelitian ini. 


\section{DAFTAR PUSTAKA}

1. American Diabetes Association. Diagnosis and Classification of Diabetes Mellitus. Diabetes Care. 2013; 36(1):67-74.

2. Anusooriya P, Malarvizhi D, Gopalakrishnan VK, and Devaki K. Antioxidant and Antidiabetic Effect of Aqueous Fruit Extract of Passiflora Ligularis Juss.on Streptozotocin Induced Diabetic Rats. International Scholarly Research Notice. 2014; 2014: 1-10.

3. George M, Joseph L, and Joseph C. Evaluation of antidiabetic Activity of leaves of Passiflora Ligularis on alloxan induced DM in albino rats. International Journal of Pharmacy and Pharmaceutical Research. 2016; 6(4): 518-522.

4. World Health Organization. Global Report on Diabetes. Geneva, Switzerland:WHO; 2016.

5. International Diabetes Federation. Diabetes Atlas, International Diabetes Federation (IDF). 5th edition. Brussel: International Diabetes Federation; 2012.

6. Ingale AG and Hivrale AU. Pharmacological Studies of Passiflora sp. and their Bioactive Compounds. African Journal of Plant Science. 2010; 4(10): 417-426.

7. Musial DC, Ostrowski AP, Ostrowski M, Bracht L, and Broetto-Biazon AC. Comparative Study of Hypocholesterolemic Potential of Pinapple and Passion Fruit Peels in Rats and Mice. Revista Brasileira de Pesquisa em Alimentos. 2015; 6(1): 64-69.

8. Kusumastuty I. Sari Buah Markisa Ungu Mencegah Peningkatan MDA Serum Tikus dengan Diet Aterogenik. Indonesian Journal of Human Nutrition. 2014; 1(1): 50-56.

9. Zas P and John S. Diabetes and Medicinal Benefits of Passiflora edulis. World Journal of Pharmaceutical Research. 2016; 5(3): 453-465.

10. Adegbite OO, Akinyemi SOS, Amao IO, and Adeoluwa OO. Consumer Awareness and Consumption of Passion Fruit in Ibadan Metropolis. Passiflora Online Journal. 2017; 10: 6-17.

11. Muntafiah A, Ermawati DA, Suryandhana L, Pratiwi RD, dan Marie IA. Pengaruh Sari Markisa Ungu (Passiflora edulis var edulis) Berbagai Dosis Profil Lipid Tikus Wistar Model Hiperkolesterolemia. Jurnal Penelitian Gizi dan Makanan. 2017; 40(1): 11-18.

12. Sharma VK, Kumar S, Patel HJ, and Hugar S. Hypoglicemic Activity of Igus Glomerata in Alloxan Induced Diabetic Rats. International Journal of Pharmaceutical Sciences Review and Research. 2010; 1(2): 18-22.

13. Kumar AY, Nandakumar K, Handral M, Talwar S, and Dhayabaran D. Hypoglicaemic and Anti-diabetic Activity of Stem Bark Extracts Erythrina Indica in Normal and Alloxan Induced Diabetic Rats. Saudi Pharmaceutical Journal. 2011; 19(1): 35-42.

14. Lachin T and Reza H. Antidiabetic Effect of Cherries in Alloxan induced Diabetic Rats. Recent Patent of Endocrine, Metabolic \& Immune Drug Discovery. 2012;6(1):67-72.

15. Shah NA and Khan KR. Antidiabetic Effect of Sida cordata in Alloxan Induced Diabetic Rats. BioMed
Research International. 2014; 2014: 1-15.

16. Balamurugan K, Nishanthini A, and Mohan VR. Antidiabetic And Antihyperlipidaemic Activity of Ethanol Extract of Melastoma Malabathricum Linn. Leaf in Alloxan Induced Diabetic Rats. Asian Pacific Journal of Tropical Biomedicine. 2014; 4(1): S442S448.

17. Akuodor GC, Udia PM, Bassey A, Chilaka KC, and Okezie OA. Antihyperglycemic and Antihyperlipidemic Properties of Aqueous Root Extract of Icacina Senegalensis in Alloxan Induced Diabetic Rats. Journal of Acute Disease. 2014; 3(2): 99-103.

18. De Sauza SS, Barbalho SM, Damasceno DC, et al. Effects of Passiflora edulis (Yellow Passion) on Serum Lipids and Oxidative Stress Status of Wistar Rats. Journal of Medicinal Food. 2012; 15(1): 78-82.

19. Muntafiah A, Yulianti D, Cahyaningtyas AH, and Damayanti HI. Pengaruh Ekstrak Jahe Merah (Zingiber Officinale) dan Madu terhadap Kadar Kolesterol Total Tikus Model Diabetes Melitus. Scripta Biologica. 2017; 4(1): 1-3

20. Ighodaro OM, Adeosun AM, and Akinloye OA. Alloxan Induced Diabetes, A Common Model for Evaluating the Glycemic-Control Potential of Therapeutic Compounds and Plants Extracts in Experimental Studies. Medicina (Kaunas). 2017; 53(6): 365-375.

21. Sarasa D, Sridhar, S, and Prabakaran E. Effect of an Antidiabetic Extract of Trigonella Foenum-Graecum on Normal and Alloxan Induced Diabetic Mice. International Journal of Pharmacy and Pharmaceutical Sciences. 2012; 4(1): 63-65.

22. Bukhari SHI, Abbasi MH, and Khan MKA. Dose Optimization of Alloxan for Diabetes in Albino Mice. Biologia (Pakistan). 2015; 61(2): 301-305.

23. Sharma B, Siddiqui MS, Kumar SS, Ram G, and Chaudhary M. Liver Protectif Effects of Aqueous extract of Syzygium cumini in Swiss Albino Mice on Alloxan Induced Diabetes Mellitus. Journal of Pharmacy Research. 2013; 6(8): 853-858.

24. Nurliyani, Harmayani E, and Sunarti. Antidiabetic Potential of Kefir Combination from Goat Milk and Soy Milk in Rats Induced with StreptozotocinNicotinamide. Korean Journal for Food Sciences of Animal Resources. 2015; 35(6): 847-858.

25. Puspati NK, Anthara MS, and Dharmayudha AAGO. Pertambahan Bobot Berat Badan Tikus Diabetes dengan Pemberian Ekstrak Etanol Buah Naga Daging Putih. Indonesia Medicus Veterinus. 2013; 2(2): 225234.

26. Salgado JM, Bombarde TAD, Mansi DN, Piedade SMS, and Meletti LMM. Effects of Different Concentration of Passion Fruit Peel (Passiflora edulis) on Glicemic Control in Diabetic Rat. Ciencia e Tecnologia de Alimentos. 2010; 30(3): 784-789.

27. Barbalho SM, Damasceno DC, Spada AP, et al. Effects of Passiflora edulis on the Metabolic Profile of Diabetic Wistar Rat Offspring. Journal of Medicinal Food. 2011; 14(12): 1490-1495.

28. Kanakasabapathi D and Gopalakrishnan VK. Evaluation of Antidiabetic Potential of Aqueous 
Extract of Passiflora edulis Sims on Alloxan Induced Diabetes Mellitus in Wistar Rats. International Journal of Pharmaceutical Sciences Review and Research. 2015; 34(1): 171-177.

29. Cazarolli LH, Zanatta L, Alberton EH, et al. Flavonoids: Cellular and Molecular Mechanism of Action in Glucose Homeostasis. Mini-Review in Medicinal Chemistry. 2008; 8(10): 1032-1038.

30. Chougale AD, Panaskar SN, Gurao PM, and Arvindekar
AU. Optimization of Alloxan Dose is Essensial to Induce Stable Diabetes for Prolonged Period. Asian Journal of Biochemistry. 2007; 2(6): 402-408.

31. Soltesova D and Herichova I. On the Mechanisms of Diabetogenic Effects of Alloxan and Streptozotocin. Diabetologie. 2011; 14(3): 130-138.

32. Jain DK and Arya RK. Anomalies in Alloxan-Induced Diabetic Model: It is Better to Standardize It First. Indian Journal of Pharmacology. 2011; 43(1): 91-91. 